\title{
Cost Estimates Related to COVID-19 Treatment in Indonesia: What Should be Concerned?
}

\author{
Sutopo Patria Jati*, Budiyono, Rani Tiyas Budiyanti, Suhartono, Praba Ginandjar, Ayun \\ Sriatmi, Nurhasmadiar Nandini \\ Faculty of Public Health, Diponegoro University, Semarang, Indonesia
}

\begin{abstract}
Coronavirus Disease-2019 (COVID-19) is a pandemic disease in all over the world caused by SARS-COV-2 virus. This disease also spread all over Indonesia. The cost of treating People Under Surveillance and Patient under Monitoring, also confirmed patient of COVID-19 will be financed by the Indonesian Government. This research aimed to identify the estimated cost for treating the Covid-19 patients in Indonesia. The calculation method used top up costs and INA CBGs based on the number of hospitalized positive patients. The data source was COVID-19 data in Central Java and national data. Case growth calculated by doubling time positive cases of COVID-19 in Central Java were 1.7 (range $1.73-2.73$ ). Range of days was between 6-8 days. The amount of top up cost for one day treatment refers to Health Ministry of Indonesia Decree Number HK.01.07/MENKES/238/2020 and cost estimation of INACBGs with the severity level II and III. This calculation did not include donations, outpatients and other costs. The result of this study, estimation if patients were treated in ICU for 8 days and non ICU for 7 days, and the rest of inpatients according to INACBs, so the cost of COVID-19 treatment for 14 - 28 days estimated at 75.7-77.3 million rupiah/patient. Whereas if the patient treated in ICU for 14 days and non ICU for 14 days, the rest of inpatient according to INACBs, the cost for COVID-19 treatment estimated at 130.4- 133.2 million rupiah/patient. The COVID-19 treatment is quite expensive and can be a burden for the Government of Indonesia's budget. In addition, the limited access and health facilities also become an obstacle. Strengthening promotive and preventive efforts are needed to prevent the surge of COVID-19 case. Policies which support strict social and physical distancing are needed so that the interventions become more effective.
\end{abstract}

Keywords. cost estimation, COVID-19 treatment

\footnotetext{
* Correspondence author : sutopopatriajati@gmail.com
} 


\section{Introduction}

Corona virus Disease-19 (Covid-19) is a pneumonia disease caused by the SARS-COV-2 virus [1]. This disease was first reported in Wuhan on 31 December 2019 [2]. World Health Organization (WHO) has declared the disease as the Public Health Emergency of International Concern (PHEIC) [3]. This caused by the transmission of the disease is very fast and the mortality rate also very high [4].

COVID-19 disease also spread in Indonesia. The first case in Indonesia was announced on 2 March 2020 and the number is keep increasing [5]. On $21^{\text {st }}$ April 2020, the number of Covid-19 patients in Indonesia reached 7,135 positive cases with 5,677 positive cases treated, 842 recovered, and 616 death. Besides, there were 16.763 patients under monitoring, and 186,330 people under surveillance. This disease also has been declared as national disaster in Indonesia [6]. The Government of Indonesia has issued several policies such as optimizing work from home, Large Scale Social Restriction, and conducting mass rapid test in several regions [7-9]. However, the policy has not yet given optimal results.

In addition to the policy regarding COVID-19, the Government of Indonesia also issued policy related to the treatment cost for the patients, including the people under surveillance, patient under monitoring, and confirmed case of COVID-19 patients which will be financed by the government. This policy refers to the Indonesian Minister of Health Regulation Number 59 Year 2016 related to Exemption of Costs for Certain Emerging Infectious Diseases [10].

The policy was followed up with the Letter of Minister of Finance Number S275/MK.02/2020 on $6^{\text {th }}$ April 2020 regarding the Norms and Provisions for the Costs of Reimbursing Patient Care for Certain Emerging Infectious Diseases for Hospitals which Providing COVID-19 services [11].

While the further technical guidelines are also contained in the regulation issued by the Indonesian Ministry of Health, namely the Decree of Indonesian Ministry of Health Number HK/01.07/MENKES/238/2020 regarding the Technical Guidelines for Claiming Reimbursement of Certain Emerging Infectious Diseases for Hospitals which Provide the COVID-19 services [12]. This financial assurance was expected to maintain the quality of health care services, cost efficiency of the services, and continuity of health care services for COVID-19 patients.

Nevertheless, the financial assurance will have an impact on the Indonesia's economy. Economic status in several countries suffers from various problems during the COVID-19 pandemic. Indonesia also claimed that the impact of COVID-19 weakened the country's economy. The worst prediction of economy condition in 2020 was minus $4 \%$ [13]. Several budget allocations have also been diverted for handling COVID-19. Therefore, the rising cases of COVID-19 will aggravate the country's economy. This research aimed to estimate the cost that will be borne by the country in providing services for COVID-19 patients and its implication on the Indonesia's economy.

\section{Methods}

This research used cross sectional approach based on the secondary data from daily report on people under surveillance, patient under monitoring, and confirmed cases of COVID-19 which obtained from the corona.jatengprov.go.id website. The top up cost referred to The Indonesian Health Minister Decree Number HK.01.07/MENKES/238/2020 and the estimation of INACBs cost in 2016.

Case estimation in this research calculated since $16^{\text {th }}$ April 2020 until $27^{\text {th }}$ May 2020 (42 days) or $10^{\text {th }}$ June 2020 (48 days). The case growth estimated 1.3 - 1.6 based doubling time 
span and it was known that the days range for Central Java Province was 6 days, while the Indonesia's day range was 10 days. The growth calculation which used on the estimation in this research was the lowest growth, as much as 1.3 and the upper margin was 1.6. Based on data from $26^{\text {th }}$ March $-16^{\text {th }}$ April 2020, it was known that the average of patient treated was $76 \%$, patients recovered was $10 \%$, died $14 \%$ of the all patients confirmed positive with COVID-19. This calculation did not include donations, outpatients and other costs. Patient non ICU were considered did not use ventilator (negative people under surveillance and patient under monitoring) as much as $68 \%$ and the ICU patient was $32 \%$ of all the patients treated in hospital. While, the ICU patient using ventilator was $60 \%$ from all the patient treated in ICU. All of the patients with status people under surveillance and patient under monitoring treated in hospital for 14 days using the top up cost and the remaining 7 days treated using the INACBGs package. The rate of people under surveillance changed status become patient under monitoring estimated around 3\%. While the rate of patient under monitoring changed status become patient confirmed positive with COVID-19 estimated around $30 \%$. The proportion of COVID-19 case in Central Java Peovince aged $>=60$ was $12.5 \%-27.3 \%$, and the average used was $20 \%$.

All the patients assumed to be hospitalized. The rates of INA CBGs Inpatient services in Hospital Type A Regional I Class 3 for government hospital include: INA CBGs rates for other lung disease (estimated COVID-19) without ventilator cost (total of maximum claimed, not per day) for severity level J-4-21-I (low level severity = I) as much as IDR 3,095,900; severity level J-4-21-II (moderate level severity = II) as much as IDR 6,913,000; severity level J-4-21-III (high level severity = III) as much as IDR 13,022,900. While, the INA CBGs rate for inpatient services in Hospital Type A Class 3 Regional I based on the rates on 2016 for private hospital include: INA CBGs rates for other lung disease (estimated COVID-19) without ventilator cost (total of maximum claimed, not per day) for severity level J-4-21-I (low level severity = I) as much as IDR 3,188,800 ; severity level J-4-21-II (moderate level severity = II) as much as IDR 7,120,400; severity level J-4-21-III (high level severity = III) as much as IDR 13,413,600.

This calculation did not include donations, outpatients and other costs. The calculations began on $16^{\text {th }}$ April 2020 and the cost estimation only until $27^{\text {th }}$ May 2020 or $10^{\text {th }}$ June 2020.

\section{Results and Discussion}

Calculation of the estimated cost needed per patient was done by using variable INACBGs rates estimation, daily top up cost, average Length of Stay/LOS (include both national and Central Java) with assumption that the patients were hospitalized. This calculation did not include donations, outpatients, other costs and corpse treatment cost.

Based on the calculation, it was estimated that there were two conditions. If the patient treated in ICU for 8 days and non ICU for 7 days, the rest of the inpatient service cost calculated using INACBGs rate, then the cost estimation of COVID-19 treatment for 14-28 days which have to be borne by the country was estimated IDR 75.7-77.3 million/patient (table 1 and table 2). 
Table 1. Estimation of the treatment cost for each patient if the LOS in ICU was 8 days and non ICU was 7 days (bottom margin)

\begin{tabular}{|c|c|c|}
\hline $\begin{array}{c}\text { Number of } \\
\text { treated patients }\end{array}$ & $\begin{array}{c}\text { Sub-Total of Treatment Cost } \\
\text { (Top Up in Rupiah/IDR) }\end{array}$ & $\begin{array}{c}\text { Average of Treatment Cost } \\
\text { (Top Up in Rupiah/IDR) }\end{array}$ \\
\hline 216 & $21,539,117,091$ & $75,841,961.59$ \\
\hline 281 & $27,990,352,218$ & $75,813,521.72$ \\
\hline 365 & $36,376,957,883$ & $75,791,644.89$ \\
\hline 474 & $47,279,545,248$ & $75,774,816.57$ \\
\hline 616 & $61,452,908,823$ & $75,761,871.70$ \\
\hline 801 & $79,878,281,470$ & $75,751,914.11$ \\
\hline 1,042 & $103,831,265,911$ & $75,744,254.43$ \\
\hline 1,354 & $134,970,145,684$ & $738,362.37$ \\
\hline
\end{tabular}

Table 2. Estimation of the treatment cost for each patient if the LOS in ICU was 8 days and non ICU was 7 days (upper margin)

\begin{tabular}{|c|c|c|}
\hline $\begin{array}{c}\text { Number of } \\
\text { treated patients }\end{array}$ & $\begin{array}{c}\text { Sub-Total of Treatment Cost } \\
\text { (Top Up in Rupiah/IDR) }\end{array}$ & $\begin{array}{c}\text { Average of Treatment Cost } \\
\text { (Top Up in Rupiah/IDR) }\end{array}$ \\
\hline 216 & $21,981,157,411$ & $77,398,441.59$ \\
\hline 281 & $28,565,004,634$ & $77,370,001.72$ \\
\hline 365 & $37,124,006,024$ & $77,348,124.89$ \\
\hline 474 & $48,250,707,831$ & $77,318,35,296.57$ \\
\hline 616 & $62,715,420,181$ & $77,308,394.11$ \\
\hline 801 & $81,519,546,235$ & $77,300,734.43$ \\
\hline 1,042 & $105,964,910,105$ & $77,294,842.37$ \\
\hline 1,354 & $137,743,883,137$ & \\
\hline
\end{tabular}

Whereas if the patient treated in ICU for 14 days and non ICU for the rest 14 days, the rest of the inpatient service cost calculated using INACBGs rate, then the cost estimation of COVID-19 treatment for 14-28 days which have to be borne by the country was estimated around IDR 130.4- 133.2 million per patient (table 3 and 4). 
Table 3. Estimation of the treatment cost for each patient if the LOS in ICU was 14 days and non ICU was 14 days (bottom margin)

\begin{tabular}{|c|c|c|}
\hline $\begin{array}{c}\text { Number of } \\
\text { treated patients }\end{array}$ & $\begin{array}{c}\text { Sub-Total of Treatment Cost } \\
\text { (Top Up in Rupiah/IDR) }\end{array}$ & $\begin{array}{c}\text { Average of Treatment Cost } \\
\text { (Top Up in Rupiah/IDR) }\end{array}$ \\
\hline 216 & $37,070,852,421$ & $130,531,170.50$ \\
\hline 281 & $48,179,808,148$ & $130,497,855.22$ \\
\hline 365 & $62,621,450,592$ & $130,472,228.09$ \\
\hline 474 & $81,395,585,770$ & $130,452,514.90$ \\
\hline 616 & $105,801,961,501$ & $130,425,686.32$ \\
\hline 801 & $137,530,249,951$ & $130,416,713.54$ \\
\hline 1,042 & $178,777,024,936$ & $130,409,811.41$ \\
\hline 1,354 & $232,397,832,417$ & \\
\hline
\end{tabular}

Table 4. Estimation of the treatment cost for each patient if the LOS in ICU was 8 days and non ICU was 7 days (upper margin)

\begin{tabular}{|c|c|c|}
\hline $\begin{array}{c}\text { Number of } \\
\text { treated patients }\end{array}$ & $\begin{array}{c}\text { Sub-Total of Treatment Cost } \\
\text { (Top Up in Rupiah/IDR) }\end{array}$ & $\begin{array}{c}\text { Average of Treatment Cost } \\
\text { (Top Up in Rupiah/IDR) }\end{array}$ \\
\hline 216 & $37,850,422,981$ & $133,276,137.26$ \\
\hline 281 & $49,191,449,876$ & $133,237,946.58$ \\
\hline 365 & $63,934,784,839$ & $133,208,569.13$ \\
\hline 474 & $83,101,120,290$ & $133,168,587.99$ \\
\hline 616 & $108,017,356,377$ & $133,155,216.37$ \\
\hline 801 & $140,408,463,290$ & $133,144,930.50$ \\
\hline 1,042 & $182,516,902,278$ & $133,137,018.30$ \\
\hline 1,354 & $237,257,872,961$ & 13399 \\
\hline
\end{tabular}

Based on the result or the cost estimation for the treatment of COVID-19 patients, the cost that will be borne by the country was quite high. Moreover, the cases keep increasing day by day and the end of the pandemic not yet to be known, it will increase the burden on the country's economy.

The rising cases did not follow by the economic readiness which causes problems in the country. Financial assurance which provided by the country will become a problem if in the implementation did not calculated thoroughly and adjusted according to the related policy. Late claims, large number of claims, and the potential for fraud might be happened which can impact the quality of health services [14].

Other problems might also occur in private hospitals which have not cooperated with the Social Security Agency. Problems related to claim will become an obstacle because according to the Decree of Indonesian Minister of Health Number 
HK.01.07/MENKES/238/2020, claim can only be made by hospitals which already cooperated with Social Security Agency [12]. If the hospital charges the health care services fees from the patients, it will be a burden for the patients, moreover there were not much health insurance that cover the fees for COVID-19 patients. This will cause inequality and affect the health care services quality.

The huge amount of money needed for COVID-19 cost treatment not only happened in Indonesia. In USA, the cost for COVID-19 treatment for 6 days estimated around USD 75.000 or estimated around USD 1,17 billion for patients which not covered by health insurance [15]. This will be an issue since the national health insurance in Indonesia have not yet covered $100 \%$ of the people in Indonesia, thought there were a lot of inactive participants which will be affect the patients to claimed their benefits of the cost claimed which financed by the country [16].

The potency of increasing COVID-19 cost treatment can be happen with the government policy that implement the new normal era in green zone area, and restricted activities in red, orange, and yellow area [17]. Although the pandemic hasn't finished yet, but the new normal has been implemented to encourage the economic condition. But, without strict health protocol and the community discipline, the number of COVID-19 cases can be larger and can be second wave COVID-19 cases. Government need to consider the huge amount of money needed and the implications, the prevention of COVID-19 is highly important to be optimized. The policy which support strict social and physical distancing are extremely needed so the intervention will be more effective.

Adopting the success of South Korea in suppressing the spread of COVID-19, the 4T principle of tracking, tracing, testing and treating can be done. Prevention in the health sector is carried out as a preventive effort through early detection with testing to the community on a large scale (testing) as an initial step, followed by subsequent steps. Advances in information technology are also utilized in the delivery of information on test results to the public, as well as a media for health promotion and monitoring [18].

Another, the community based resilience must be strengthened so that it can prevent the surge of COVID-19 case. The strategy to reduce risk massively and participatively in preventing the spread of the COVID-19 pandemic starts from the lowest social level, namely individuals, families, RT / RW communities, villages and so on to the national level. Thus community participation will be built to reduce the potential for transmission, while creating aspects of national resilience in the face of a pandemic. Required policy frameworks related to regulation, institutional and financing to increase its effectiveness [19]. The results of a study conducted by the PRAKARSA Society on COVID-19 multidimensional risk also showed that an effective social restriction policy could significantly reduce the number of people affected by COVID-19[20].

\section{Conclusion}

The COVID-19 treatment is quite expensive, moreover if the cases keep increasing significantly. This can be a burden for the Government of Indonesia's budget. In addition, the limited access and health facilities also become an obstacle. Strengthening promotive and preventive efforts are needed to prevent the surge of COVID-19 case. Policies which support strict social and physical distancing are needed so that the interventions become more effective. 


\section{References}

1. Di Wu, Tiantian Wu, Qun Liu, Zhicong Yang, et al. The SARS-Cov-2 Outbreak: What We Know. International Journal of Infectious Disease. (2020). Vol 94, pp. 44-48

2. Holshue ML, DeBolt C, Lindquist S, et al. First case of 2019 Novel Coronavirus in the United States. N Enlh J Med. (2020)

3. World Health Organization (WHO). COVID-19 Public Health Emergency of International Concern (PHEIC) Global research and innovation forum. February 2020. Available at: https://www.who.int/publications/m/item/covid-19-public-healthemergency-of-international-concern-(pheic)-global-research-and-innovation-forum (Accessed: $20^{\text {th }}$ June 2020)

4. Jin Y, Cai L, Cheng Z, et al. A rapid advice guidline for the diagnosis and treatment of 2019 novel coronavirus (2019-nCoV) infected pneumonia (standard version). Mil Med Res 2020; 7:4

5. Ratcliffe, Rebecca. "First coronavirus cases confirmed in Indonesia amid fears nation is ill-prepared for an outbreak". The Guardian. Retrieved 2 March 2020.

6. COVID-19 Indonesian Task Force. Case Number COVID-19 in Indonesia. Available at : https://covid19.go.id/

7. Ihsanudin. Jokowi Perintahkan Rapid Test Masal. Available at: https://nasional.kompas.com/read/2020/03/19/12005241/jokowi-perintahkan-gelarrapid-test-covid-19-massal (Accesed : $20^{\text {th }}$ June 2020)

8. Ministry of Health Indonesia. Ministry of Health Regulation No. 9 the Year 2020 concerning the Large Scale Social Limitations Guidelines in the Framework of the Acceleration of COVID-19 Handling.

9. Rizky Fachriansyah. Work From Home Policy in Effect at Major Jakarta Companies over Virus Concern. Available at : https://www.thejakartapost.com/news/2020/03/15/work-from-home-policy-in-effect-atmajor-jakarta-companies-over-virus-concerns.html

10. Ministry of Health Indonesia. Indonesian Minister of Health Regulation Number 59 Year 2016 related to Exemption of Costs for Certain Emerging Infectious Diseases

11. Minister of Finance Indonesia. Letter of Minister of Finance Number S275/MK.02/2020 on $6^{\text {th }}$ April 2020 regarding the Norms and Provisions for the Costs of Reimbursing Patient Care for Certain Emerging Infectious Diseases for Hospitals which Providing COVID-19 services

12. Minister of Health Indonesia. Decree of Indonesian Ministry of Health Number HK/01.07/MENKES/238/2020 regarding the Technical Guidelines for Claiming Reimbursement of Certain Emerging Infectious Diseases for Hospitals which Provide the COVID-19 services

13. Adrian Wail Akhlas. Chrisis like no other will shrink Indonesia economy, IMF forecast. Available at: https://www.thejakartapost.com/news/2020/06/25/crisis-like-no-otherwill-shrink-indonesias-economy-imf-forecasts.html (Accesed : $30^{\text {th }}$ June 2020)

14. Calvin A. Covid-19 Fraud: Law Enforcement;s Response to Those Exploiting the Pandemic. Available at: https://www.fbi.gov/news/testimony/covid-19-fraud-lawenforcements-response-to-those-exploiting-the-pandemic

15. Megan Leonhart. Hospital Biils Could Cost Unisured Americans up to 75000 dollars. Available at : https://www.cnbc.com/2020/04/01/covid-19-hospital-bills-could-costuninsured-americans-up-to-75000.htm (Accesed : $24^{\text {th }}$ June 2020)

16. Rina Agustina, Teguh Dartanto, Ratna Sitompul, et al. Universal health coverage in Indonesia: concept, progress, and challenge. Vol: 393, pp: 75-102. Available at: https://www.thelancet.com/journals/lancet/article/PIIS0140-6736(18)31647-7/fulltext 
17. Indonesian Office of Assistant to Deputy Cabinet Secretary for State Documents and Translation. 102 Regions Get Green Light to Implement New Normal. Available at : https://setkab.go.id/en/102-regions-get-green-light-to-implement-new-normal/ (Accesed: $30^{\text {th }}$ June 2020)

18. Sari MI. Kebijakan Korea Selatan dalam Meratakan Kurva COVID-19 tanpa Lockdown: Sebuah Pelajaran. THC INSIGHTS - The Habibie Centre (2020); 7.

19. Hadi S. Pengurangan Risiko Pandemi Covid-19 Secara Partisipatif: Suatu Tinjauan Ketahanan Nasional terhadap Bencana. J Perenc Pembang Indones J Dev Plan 2020; 4: 177-190.

20. Thaariq RM, Wahyu MFR, Ningrum DR, et al. Kemiskinan Multidimensi dan Risiko COVID-19 di Indonesia. PRAKARSA Work Pap No01 (2020); 01: 1-29. 